\title{
The Japanese Encephalitis Serological Group of Flaviviruses: a Brief Introduction to the Group
}

\author{
J.S. Mackenzie ${ }^{1}$, A.D.T. Barrett ${ }^{2}$, and V. Deubel ${ }^{3}$
}

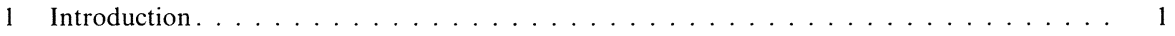

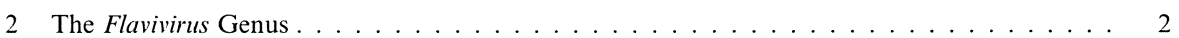

3 The Japanese Encephalitis Serological Group . . . . . . . . . . . . . . . . . . . . 3

3.1 St. Louis Encephalitis Virus . . . . . . . . . . . . . . . . . . . . . . . . . 6

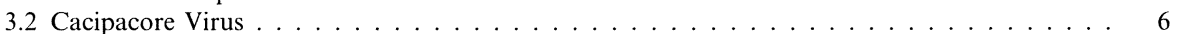

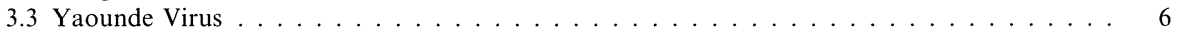

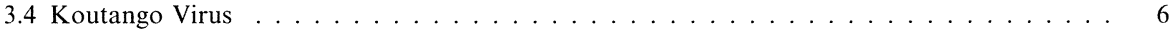

3.5 Usutu Virus . . . . . . . . . . . . . . . . . . . . . . . . . . . 7

3.6 Murray Valley Encephalitis Virus . . . . . . . . . . . . . . . . . . . 7

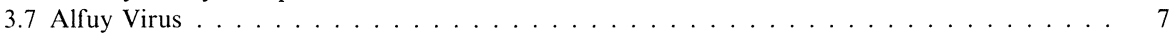

4 Comments on the Classification of the JE Serological Group Viruses . . . . . . . . . . . 8

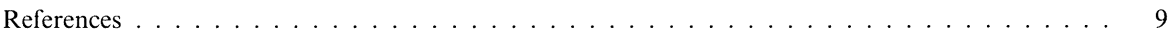

\section{Introduction}

Japanese encephalitis (JE) and West Nile (WN) viruses are two of the four major encephalitic flaviviruses of public health importance in the Japanese encephalitis serological group, the other two being St. Louis encephalitis (SLE) virus in North America and Murray Valley encephalitis (MVE) virus in Australasia. JE and WN share a number of similarities, including natural transmission cycles involving avian reservoir hosts and culicine mosquitoes and their ability to cause fatal infections in horses. The two viruses also differ in aspects of their transmission cycles and in their host range. Thus, unlike WN virus, JE virus also has a major mammalian amplifying host in the pig, and indeed most epidemic activity is driven by mosquito-pig transmission cycles. Some strains of WN virus, on the other hand, can cause a fatal disease in both domestic geese and various species of wild birds. However, most importantly, they also share a propensity to emerge and become established in new

\footnotetext{
${ }^{1}$ Department of Microbiology and Parasitology, The University of Queensland, Brisbane, Queensland 4072, Australia

${ }^{2}$ Center for Tropical Diseases, and Department of Pathology, University of Texas Medical Branch, Galveston, TX 77555-0605, USA

${ }^{3}$ Centre de Recherche Mérieux Pasteur à Lyon, 21 Avenue Tony Garnier, 69365 Lyon Cedex 7. France 
geographic areas. The recent spread of JE virus into western Asia and Australasia has probably been through natural mosquito-vertebrate host cycles, possibly assisted by changes in land use. However, the most recent example of the emergence of WN virus in New York and its subsequent spread in the eastern seaboard of the United States, was almost certainly due to inadvertent human involvement through transportation of either a viraemic human or bird, or an infected mosquito, from Israel or the Middle East. Although JE virus appears to have become established in New Guinea, it has not yet done so in Pakistan or in mainland Australia (Mackenzie et al., this volume). WN virus, however, appears to have now become well established in the eastern seaboard of the United States (Roehrig et al., this volume). Thus in 1999, the original incursion and subsequent epidemic activity was centred on New York city and adjacent counties in New York, New Jersey and Connecticut. In 2000, the virus spread throughout New York State and infected birds were found in 11 other states and in Washington DC. The spread has gathered momentum in 2001, and at the time of writing (beginning of September 2001) has spread south into Alabama, Florida, Georgia, and Louisiana; west into Kentucky, Indiana, Michigan and Ohio; and north into Ontario. Indeed, a total of 99 counties/parishes in 16 states and the District of Columbia have had confirmed findings of WN virus in a mosquito, bird, horse, or human, since 1 January 2001 (ProMED 2001a,b). Of additional interest, a concurrent outbreak of SLE has been reported from Louisiana, thus potentially complicating the diagnoses in that State (ProMED 2001c).

The two viruses are major causes of disease in their respective geographic areas. JE virus is responsible for more than 50,000 cases of encephalitis annually in eastern, south-eastern and southern Asia, with a fatality rate of about $25 \%$. In addition, increasing tourism and travel are placing greater numbers of people at risk of infection. WN virus has been responsible for major outbreaks of human encephalitis in Algeria in 1994, Romania in 1996, Tunisia in 1997, south-western Russia in 1999, and Israel in 2000, and equine encephalitis in Morocco in 1996, Italy in 1998, and France in 2000. Indeed, there has been a change in the spectrum of human disease due to WN virus over the past decade, with the emergence of an increased incidence of encephalitic infections. Thus, with their recent spread into new areas, and the severity of the disease they can cause, there has been a greater public health awareness of both viruses. This paper describes the Japanese encephalitis serological group and its members as a prelude to the remainder of the volume, which explores aspects of the ecology, epidemiology and pathobiology of JE and WN (and its newly classified subtype, Kunjin virus).

\section{The Flavivirus Genus}

The Flavivirus genus in the family Flaviviridae comprises approximately 70 antigenically related members. Most members are arboviruses, transmitted by 
arthropod vectors, either ticks or mosquitoes, and usually replicate alternately in susceptible vertebrate and arthropod hosts. A few viruses have no known vectors. The most recent classification, as listed in the 7th Report of the International Committee on Taxonomy of Viruses (ICTV), has assigned members of the genus into species, with some members demoted to strains or serotypes (HeINZ et al. 2000). Thus there are now 27 mosquito-borne species, 12 tick-borne species, and 14 species with no known vector. The current classification of the mosquitoborne flaviviruses, their major vectors and hosts, their geographic range, and their virulence for humans, is shown in Table 1. The major criteria for determining the groupings of species, strains and serotypes within the genus are nucleotide and deduced amino acid sequence data, antigenic relationships, vector association and geographic incidence. The interpretation of the criteria for assigning a species level, and the definition of what constitutes a 'strain' or 'serotype' may be controversial in some instances, and indeed changes may be necessary as more information becomes available. Perhaps a more useful indication of relationships between flaviviruses can be obtained from phylogenetic studies which tend to agree with antigenic and vector/host relationships (e.g., Kuno et al. 1998; ZanOtTo et al. 1996; Billoir et al. 2000; Jenkins et al. 2001; Gould et al. 2001).

\section{The Japanese Encephalitis Serological Group}

The Japanese encephalitis virus serological group currently comprises eight species and two strains or subtypes (Table 1), as listed in the 7th Report of the ICTV (HeInz et al. 2000). It is perhaps the most important Flavivirus group on a global scale, with members endemic to all continents except the Antarctic. They cause diseases ranging from febrile illness, with or without a rash and with or without myalgia, to a meningo-encephalitis with significant mortality, although most infections are subclinical or inapparent. All members of the group are believed to have natural maintenance cycles alternating between birds and mosquitoes, and in many cases, ardeid birds and culicine mosquitoes. The only member that has not been isolated from an arthropod is Cacipacore virus. Isolations of some members of the group have occasionally been reported from ticks, including SLE virus (MCLEAN et al. 1985), WN virus (reviewed in HubÁlek and Halouzka 1999; Rapport AnNuel 1998), JE virus (Lvov 1978), and Koutango virus (RAPPORT ANNUEL 1998). Indeed Koutango virus has been isolated more frequently from ticks than from mosquitoes (see below). JE virus has also been isolated from a midge, Lasiohelea taiwana, collected while biting humans in China (C.-J. Wu and S.-Y. Wu, cited by Rosen 1986). The ecology and epidemiology of members of the group, other than JE and WN (and its subtype Kunjin virus) viruses, the subjects of this volume, are summarised briefly below. 


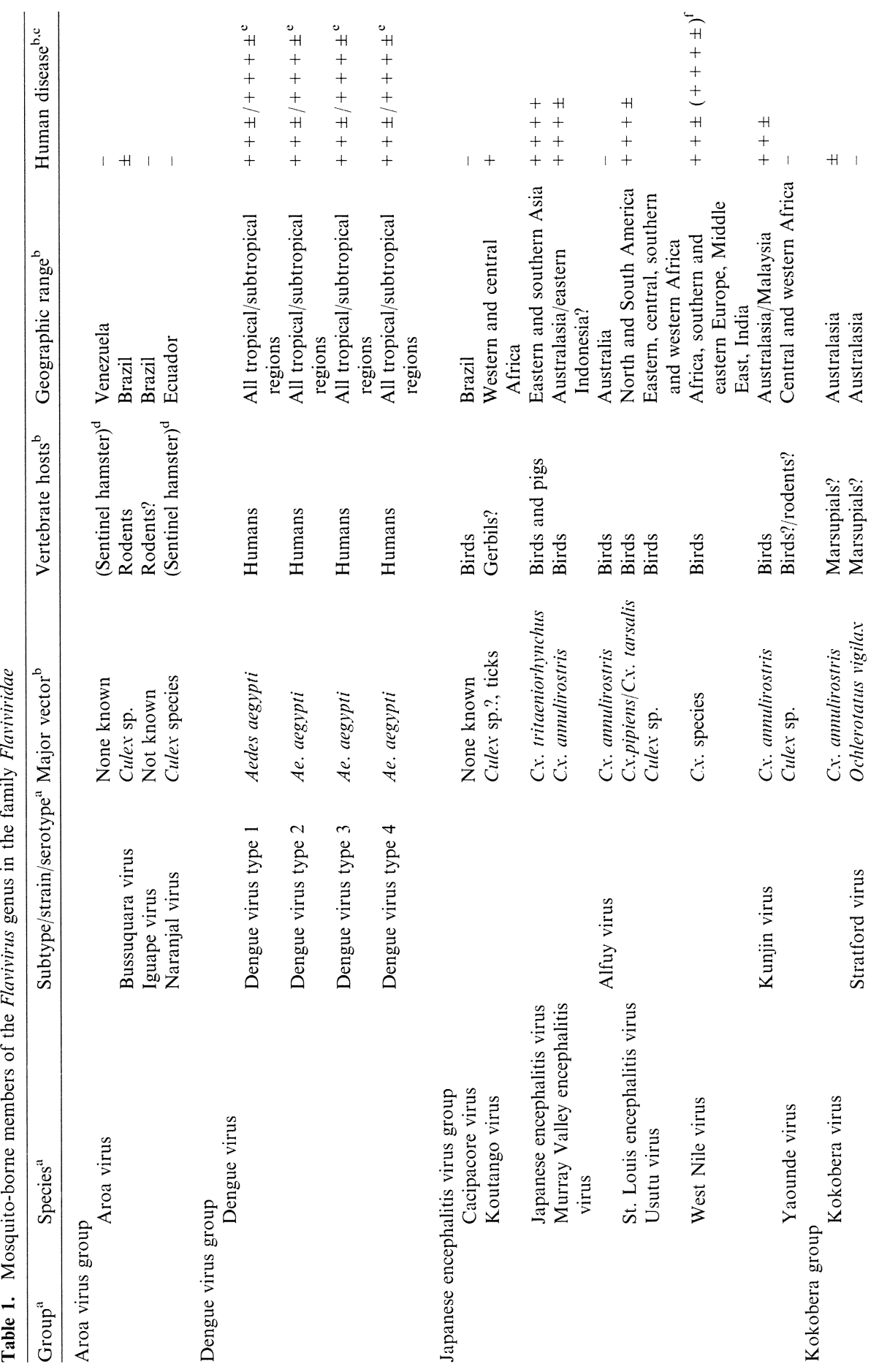




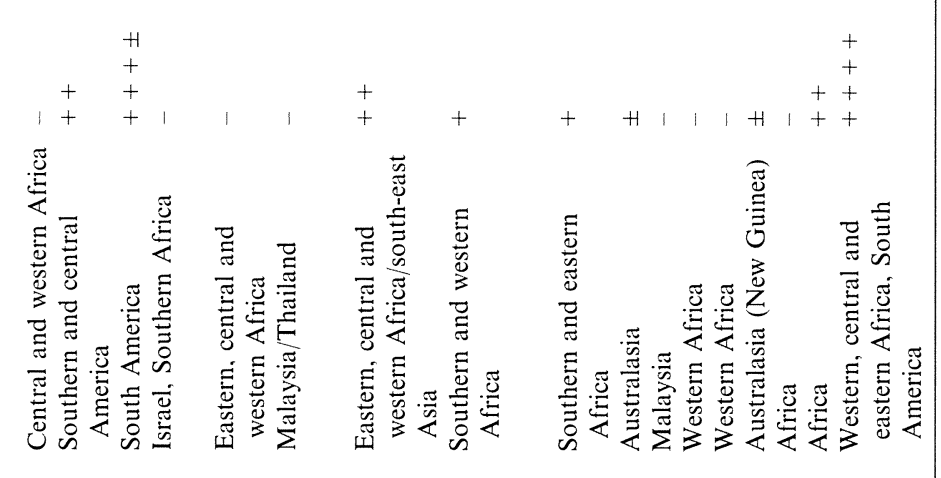

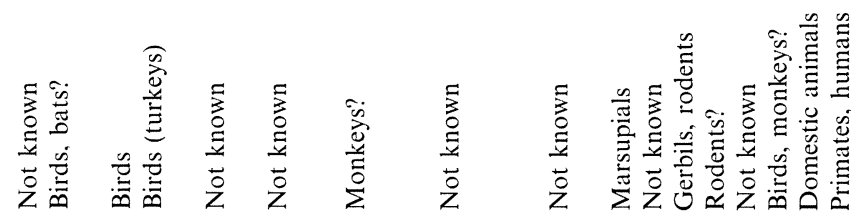
空+

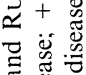<smiles>C1CCCC1</smiles>

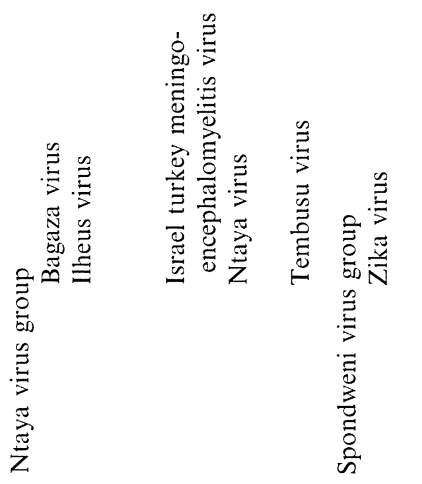

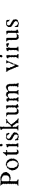
要

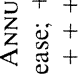
产

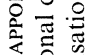
$\simeq$. 


\subsection{St. Louis Encephalitis Virus}

The ecology and epidemiology of SLE have been reviewed extensively by TSAI and Mitchell (1988) and by DAY (2001). The geographic range of SLE extends from southern Canada to Argentina, although human cases have occurred almost exclusively in the United States, and particularly in the central and eastern states (MONATH 1980). Humans are the only host to suffer disease and death following natural infection by SLE virus. The major vertebrate maintenance and amplifying hosts of SLE are birds, especially members of the Passeriformes and Columbiformes, but water birds may be important in Central America (McLean and Bowen 1980; SPENCE 1980). The major vector species in different areas are Culex tarsalis, Cx. pipiens, Cx. p. qinquefasciatus, and Cx. restuans (Mrtchell et al. 1980). Although SLE has been reported to infect a number of mammals, as demonstrated by serological studies or virus isolation, mammals are not thought to play a major role in natural transmission cycles in North America, although they may be involved in Central and South America (Tsai and Mitchell 1989; Spence 1980). SLE virus has been isolated from racoons, opossums, an impala, and Mexican free-tailed bats in North America, and from a three-toed sloth, monkeys and rodents in South America.

\subsection{Cacipacore Virus}

Cacipacore virus was first included in the Japanese encephalitis serological group in the 7th Report of the ICTV (Heinz et al. 2000). Cacipacore virus was isolated in 1977 from a bird in Pará State in the Amazon area of Brazil (Travassos et al. 1998). No further isolates have been reported from any source (L.T. Figueiredo, personal communication), so the vector remains unknown. It has not been associated with human disease. Phylogenetic studies show that although it is one of the most divergent members of the group, it is the closest New World member (KUNO et al. 1998; Jenkins et al. 2001; Gould et al. 2001; Batista et al. 2001).

\subsection{Yaounde Virus}

Yaounde virus was first included in the JE serological group in the 7th Report of the ICTV. It has been isolated from mosquitoes, a bird and mammals (rodents) in Cameroun, Central African Republic, Congo, and Senegal (RApport Annuel 1998). It has not been associated with human disease. Little information is available about properties of the virus.

\subsection{Koutango Virus}

Koutango virus is closely related to WN virus. It was first isolated from a Kemp's gerbil (Tatera kempi) in 1969 in Senegal. Only one isolate has been reported from 
mosquitoes (Culex neavei) in Senegal, but with a further 10 isolates from ticks, 21 isolates from mammals (rodents), and one human isolate (KARABATsos 1985; RAPPORT ANNuEl 1998). Most isolates have been obtained from Senegal, with a few from Central African Republic. It has been associated with occasional human infections resulting in fever, rash and arthralgia.

\subsection{Usutu Virus}

Usutu virus was first isolated from $C x$. neavei mosquitoes in Natal, South Africa in 1969. Subsequent isolates have been reported from Uganda, Nigeria, Central African Republic, Cameroun, and Senegal from mosquitoes, rodents and birds, and from one human serum specimen (Karabatsos 1985; RAPPPORT ANNuEL 1998). The single human infection presented with fever and rash. Phylogenetically, Usutu virus is closely related to JE virus, and indeed groups more closely with JE, MVE and Alfuy viruses than it does to the other African viruses - WN, Yaounde, and Koutango viruses (JENKINS et al. 2001; Gould et al. 2001; Kuno et al. 1998).

\subsection{Murray Valley Encephalitis Virus}

MVE virus is the major encephalogenic flavivirus in Australasia (Australia and Papua New Guinea). It was first isolated in 1951 from a human case during a major outbreak in south-eastern Australia, and from Culex annulirostris mosquitoes in 1959 at Kowanyama, Cape York, northern Queensland. Natural transmission cycles are believed to be between ardeid water birds and $C x$. annulirostris mosquitoes (MARShall 1988). Indeed more than $90 \%$ of all MVE isolations have been made from this mosquito species (MAckenzie et al. 1994; Russell 1995). Although serological studies have shown that various mammals can also be infected, they are not believed to play a significant role in natural transmission cycles. The virus is believed to be enzootic in the north of Western Australia and the Northern Territory, and possibly in northern Queensland (SPENCER et al. 2001). It is also enzootic in Papua New Guinea and parts of the eastern Indonesian archipelago (MACKENZIE et al. 1994). Epidemics of MVE occurred in south-eastern Australia in 1951 and 1974, with a few cases in 1956 and 1971, but all cases since 1974 have been from northern Australia (Marshall 1988; Mackenzie et al. 1993, 1998; Cordova et al. 2000).

\subsection{Alfuy Virus}

Alfuy virus was first isolated from a swamp pheasant (Centropus phasiainus) in 1966 at Kowanyama, Cape York, northern Queensland. All subsequent isolations have been from mosquitoes, including Aedeomyia catasticta, Cx. annulirostris, and $C x$. pullus, trapped in northern Western Australia and Queensland. Phylogenetically, 
Alfuy virus falls between MVE and JE viruses, but is slightly closer to MVE. There have been no confirmed cases of human disease due to Alfuy virus.

\section{Comments on the Classification of the JE Serological Group Viruses}

Although membership of the group has been defined using a number of criteria, including nucleotide sequence analyses (e.g. KuNO et al. 1998; BILLOIR et al. 2000; JENKIns et al. 2001) and antigenic cross-reactivity (DE MADRID and PorTERFIELD 1974; CALISHER et al. 1989), as well as vector and vertebrate host similarities, there are inconsistencies that need to be addressed. One such inconsistency is SLE virus which is listed as a member of the JE serological group based largely on antigenic cross-reactivity (De MAdrid and Porterfield 1974; CAlisher et al. 1989) and ecology, but from nucleotide sequence analyses, it is clearly closer to two South American viruses in the Ntaya virus serological group, Rocio and Ilheus viruses (Kuno et al. 1998; Gould et al. 2000; JENKINs et al. 2001). In addition, Alfuy virus has been classified as a subtype of MVE virus, but recent sequencing and biological data would suggest that this may have been premature (MAY et al. 2001; F.J. May, R.A. Hall, J.S. Mackenzie, unpublished results). Conversely, Kokobera and Stratford viruses, two Australian viruses that had been included in the JE serological group in the 6th report of the ICTV (WENGLER et al. 1995), have been removed on genetic (PoIDINGER et al. 1996; Kuno et al. 1998) and, to a lesser extent, antigenic (Westaway 1968; CAlisher et al. 1989) grounds, and placed into a new group of their own in the 7th Report of the ICTV (Heinz et al. 2000).

The other inconsistency that needs to be considered is the wide nucleotide sequence variation between WN virus isolates. Berthet and colleagues (BERTHET et al. 1997) clearly demonstrated that there were two distinct genetic lineages of WN viruses. This was confirmed and extended in other studies (JIA et al. 1999; Lanciotti et al. 1999; Savage et al. 1999; Scherret et al. 2001). One lineage, lineage I, comprises four major clades including most isolates from Africa, Europe and India, as well as the New York isolates and the Australian Kunjin viruses; the second lineage comprises the original prototype strain, and isolates from West, Central and East Africa, and from Madagascar. Interestingly, human disease is rarely recognised from lineage II WN viruses. The maximum nucleotide divergence between members of the two lineages was shown to range from $29 \%$ (BERTHET et al. 1997 ) and $31 \%$ (ScherRet et al. 2001) for sequences within the E gene, to $36.5 \%$ for sequences in the NS5-3' untranslated region (SCHERRET et al. 2001), which would suggest that the lineages may represent two distinct viruses. We therefore propose that they should be re-named West Nile subtype 1 and West Nile subtype 2 , rather like the dengue viruses, or alternatively, that the name West Nile be retained for the viruses in lineage II, as this lineage contains the prototype strain, and that viruses in lineage I be renamed. Finally the majority of West Nile strains 
from India are classified as a distinct clade within lineage I, yet there is low bootstrap support for this conclusion. Further studies are warranted to confirm their inclusion in lineage $\mathrm{I} /$ West Nile subtype 1 , or whether they should also be considered to represent a different lineage.

\section{References}

Batista WC, Kashima S, Marques AC, Figueiredo LTM (2001) Phylogenetic analysis of Brazilian Flavivirus using nucleotide sequences of parts of NS5 gene and $3^{\prime}$ non-coding regions. Virus Res 75:35-42

Berthet FX, Zeller HG, Drouet MT, Rauzier J, Digoutte JP, Deubel V (1997) Extensive nucleotide changes and deletions within the envelope glycoprotein gene of Euro-African West Nile viruses. J Gen Virol 78:2293-2297

Billoir F, de Chesse R. Tolou H, de Micco P. Gould EA, de Lamballerie X (2000) Phylogeny of the genus Flavivirus using complete coding sequences of arthropod-borne viruses and viruses with no known vector. J Gen Virol 81:781-790

Calisher CH, Karabatsos N, Dalrymple JM. Shope RE, Porterfield JS, Westaway EG, Brandt WE (1989) Antigenic relationships between flaviviruses as determined by cross-neutralization tests with polyclonal antisera. J Gen Virol 70:37-43

Cordova SP, Smith DW, Broom AK, Lindsay MD, Dowse GK, Beers MY (2000) Murray Valley encephalitis in Western Australia in 2000, with evidence of southerly spread. Comm Dis Intell 24: 368-372

Day JF (2001) Predicting St. Louis encephalitis virus epidemics: lessons from recent, and not so recent, outbreaks. Ann Rev Entomol 46:111-138

De Madrid AT, Porterfield JS (1974) The flavivirus (group B arboviruses): a cross-neutralisation study. J Gen Virol 23:91-96

Figueiredo LTM (2000) The Brazilian flaviviruses. Microbes Infect 2:1643-1649

Gould EA, de Lamballerie X, Zanotto PMA, Holmes EC (2001) Evolution, epidemiology and dispersal of flaviviruses revealed by molecular phylogenies. Adv Virus Res 57:71-103

Heinz FX, Collett MS, Purcell RH, Gould EA, Howard CR, Houghton M, Moormann RJM, Rice CM, Thiel HJ (2000) Flaviviridae. In: van Regenmortel MHV, Fauquet CM, Bishop DHL, Carstens EB, Estes MK, Lemon SM, Maniloff J, Mayo MA, McGeoch DJ, Pringle CR, Wickner RB (eds) Virus Taxonomy. Classification and nomenclature of viruses. 7th Report of the International Committee for the Taxonomy of Viruses. Academic Press, San Diego, pp 859-878

Hubálek Z, Halouzka J (1999) West Nile fever - a reemerging mosquito-borne viral disease in Europe. Emerg Infect Dis 5:643-650

Jenkins GM, Pagel M, Gould EA, Zanotto PMA, Holmes EC (2001) Evolution of base composition and codon usage bias in the genus Flavivirus. J Mol Evol 52:383-390

Jia XY, Briese T, Jordan I, Rambaut A, Chi HC, Mackenzie JS, Hall RA, Scherret J, Lipkin WI (1999) Genetic analysis of the West Nile New York encephalitis virus. Lancet 354:1971-1972

Karabatsos N (ed) (1985) International Catalogue of Arboviruses, 3rd Edition. American Society of Tropical Medicine and Hygiene, San Antonio, Texas

Kuno G, Chang G-JJ, Tsuchiya KR, Karabatsos N, Cropp CB (1998) Phylogeny of the genus Flavivirus. J Virol 72:73-83

Lanciotti RS, Roehrig JT, Deubel V. Smith J, Parker M, Steele K, Volpe KE, Crabtree JH, Scherret JH, Hall RA, Mackenzie JS, Cropp CB, Panigrahy B, Ostlund E, Schmitt B, Malkinson M. Banet C, Weisman J, Komar N, Savage HM, Stone W. McNamara T, Gubler DJ (1999) Origin of the West Nile virus responsible for an outbreak of encephalitis in the northeastern U.S. Science 286:2333-2337

Lvov DK (1978) The role of ixodid ticks in the reservation and transmission of arboviruses in the USSR. In: Wilde TKH (ed) Tick-Borne Diseases and their Vectors. Lewis Reprints, Tonbridge, UK, pp 482-486

Mackenzie JS, Smith DW, Broom AK, Bucens MR (1993) Australian encephalitis in Western Australia, 1978-1991. Med J Aust 158:591-595 
Mackenzie JS, Lindsay MD, Coelen RJ, Broom AK, Hall RA. Smith DW (1994) Arboviruses causing human disease in the Australasian zoogeographic region. Arch Virol 136:447-467

Mackenzie JS, Broom AK, Hall RA, Johansen CA, Lindsay MD, Phillips DA, Ritchie SA, Russell RC. Smith DW (1998) Arboviruses in the Australian region, 1990 to 1998. Comm Dis Intell 22:93-100

McLean RG. Bowen SB (1980) Vertebrate hosts. In: Monath TP (ed) St. Louis Encephalitis. American Public Health Association. Washington DC, pp 381-450

McLean RG, Francy DB, MonathTP, Calisher CH. Trent DW (1985) Isolation of St. Louis encephalitis virus from adult Dermacentor variabilis (Acari: Ixodidae). J Med Entomol 22:232-233

Marshall ID (1988) Murray Valley and Kunjin encephalitis. In: Monath TP (ed) The Arboviruses: Epidemiology and Ecology, Volume III. CRC Press, Boca Raton, pp 151-190

May FJ, Nisbet DJ, Mackenzie JS. Hall RA (2001) Alfuy virus: an virulent subtype of MVE virus? In: Scientific Program and Abstracts. Sixth International Symposium on Positive Strand Viruses, Institut Pasteur, Paris, pp 2-86

Mitchell CJ, Francy DB, Monath TP (1980) Arthropod vectors. In: Monath TP (ed) St. Louis Encephalitis. American Public Health Association, Washington DC, pp 313-379

Monath TP (1980) Epidemiology. In: Monath TP (ed) St. Louis Encephalitis. American Public Health Association, Washington DC, pp 239-312

Poidinger M. Hall RA, Mackenzie JS (1996) Molecular characterisation of the Japanese encephalitis serocomplex of the Flavivirus genus. Virology 218:417-421

ProMED (2001a) Findings of West Nile virus reported from 1 Jan through 22 Aug 2001. West Nile Virus Surveillance - USA (18), ProMED posting, August 25, 2001

ProMED (200lb) West Nile virus, horse - USA (Kentucky), ProMED posting, September 1, 2001

ProMED (2001c) ST. Louis encephalitis - USA (Louisiana), ProMED posting, August 29, 2001

Rapport Annuel (1998) Centre Collaborateur OMS de Reference et de Recherche pour les Arbovirus et Virus de Fievres Hemorragiques. Institut Pasteur de Dakar, Senegal

Rosen L (1986) The natural history of Japanese encephalitis virus. Ann Rev Microbiol 40:395-414

Russell RC (1995) Arboviruses and their vectors in Australia: an update on the ecology and epidemiology of some mosquito-borne arboviruses. Rev Med Vet Entomol 83:141-158

Savage HM, Ceianu C, Nicolescu G, Karabatsos N, Lanciotti R, Vladimirescu A, Laiv L, Ungureanu A, Romanca C, Tsai TF (1999) Entomologic and avian investigations of an epidemic of West Nile fever in Romania in 1996, with serologic and molecular characterization of a virus isolate from mosquitoes. Am J Trop Med Hyg 61:600-611

Scherret JH, Poidinger M, Mackenzie JS, Broom AK, Deubel V, Lipkin WI, Briese T, Gould EA, Hall RA (2001) Studies on the relationships between West Nile and Kunjin viruses. Emerg Infect Dis 7:697-705

Spence L (1980) St. Louis encephalitis in tropical America. In: Monath TP (ed) St. Louis Encephalitis. American Public Health Association, Washington DC, pp 451-472

Spencer JD, Azoulas J, Broom AK, Buick TD, Daniels PW, Doggett SL, Hapgood GD, Jarrett PJ, Lindsay MD, Lloyd G, Mackenzie JS, Merianos A, Moran RJ, Ritchie SA, Russell RC, Smith DW, Stenhouse FO, Whelan PI (2001) Murray Valley encephalitis virus surveillance and control initiatives in Australia. Comm Dis Intell 25:33-47

Travassos da Rosa JFS, Travassos da Rosa APA, Vasconcelos PFC, Rodrigues SG, Travassos da Rosa ES, Dias LB, Cruzi ACR (1998) Arboviruses isolated in the Evandro Chagas Institute, including some described for the first time in the Brazilian Amazon region, their known hosts, and their pathology for man. In: Travassos da Rosa APA, Vasconcelos PFC, Travassos da Rosa JFS (eds) An Overview of Arbovirologyin Brazil and Neighboring Countries. Institiuto Evandro Chagas, Belem, pp 19-31

Tsai TF, Mitchell, CJ (1989) St. Louis encephalitis, In: Monath TP (ed) The Arboviruses: Epidemiology and Ecology, Volume IV. CRC Press, Boca Raton, USA, pp 113-143

Wengler G, Bradley DW, Collett MS, Heinz FX, Schlesinger RW, Strauss JH (1995) Flaviviridae. In: Murphy FA, Fauquet CM, Bishop DHL, Ghabrial SA. Jarvis AW, Martelli GP, Mayo MA, Summers MD (eds) Virus Taxonomy. Sixth Report of the International Committee on Taxonomy of Viruses, Arch Virol Suppl 10, Springer-Verlag, Vienna, pp 415-427

Westaway EG (1968) Greater specificity of 19S than 7S antibodies on haemagglutinin inhibition tests with closely related group B viruses. Nature 219:78-79

Zanotto PM, Gould EA, Gao GF. Harvey PH, Holmes EC (1996) Population dynamics of flaviviruses revealed by molecular phylogenies. Procs Natl Acad Sci USA 93:548-553 